\title{
Preventive effect of Lactobacillus plantarum KSFY02 isolated from naturally fermented yogurt from Xinjiang, China, on D-galactose-induced oxidative aging in mice
}

\author{
Xin Zhao, ${ }^{1}$ Ruokun Yi, ${ }^{1}$ Xianrou Zhou, ${ }^{1,2}$ Jianfei Mu,,${ }^{1,2}$ Xingyao Long, ${ }^{1,3}$ Yanni Pan,,${ }^{1,3}$ Jia-Le Song, ${ }^{4 *}$ \\ and Kun-Young Park ${ }^{1,3 *}$ \\ ${ }^{1}$ Chongqing Collaborative Innovation Center for Functional Food, Chongqing University of Education, Chongqing 400067, China \\ ${ }^{2}$ College of Food Science, Southwest University, Chongqing 400715, China \\ ${ }^{3}$ Department of Food Science and Biotechnology, Cha University, Seongnam, Gyeonggi 13488, Korea \\ ${ }^{4}$ Department of Nutrition and Food Hygiene, School of Public Health, Guilin Medical University, Guilin, Guangxi 541004, China
}

\section{ABSTRACT}

Yogurt from Xinjiang, China, is a traditional and naturally fermented food, and abundant microorganisms are produced during its fermentation process. In this study, we carried out in vivo animal experiments to explore the effect of a newly isolated lactic acid bacterial strain, Lactobacillus plantarum KSFY02 (LPKSFY02), on oxidative aging. We used D-galactose to induce oxidative aging in mice and analyzed the serum and tissues of those mice using molecular biology detection methods. The results showed that LP-KSFY02 could inhibit the decreases in the thymic, cerebral, cardiac, liver, spleen, and kidney indices of mice caused by oxidative aging. The LP-KSFY02 strain increased activity of superoxide dismutase (SOD), glutathione peroxidase (GSH-Px), and glutathione (GSH) and reduced levels of nitric oxide (NO) and malondialdehyde in the serum, liver, and spleen of the oxidative aging mice. Pathological observation demonstrated that LPKSFY02 alleviated damage to the liver and spleen of oxidative aging mice. Quantitative PCR showed that LP-KSFY02 effectively upregulated mRNA expression of neuronal nitric oxide synthase (Nos1), endothelial nitric oxide synthase (Nos3), copper/zinc superoxide dismutase (Sod1), manganese superoxide dismutase (Sod2), catalase (Cat), heme oxygenase-1 (Hmox1), nuclear factor erythroid 2 related factor 2 (Nfe2l2), $\gamma$-glutamylcysteine synthetase $($ Gclm $)$, and quinone oxidoreductase 1 (Nqo1) in mouse liver and spleen and downregulated expression of inducible nitric oxide synthase (Nos2). Western blot analysis revealed that

\footnotetext{
Received November 22, 2018.

Accepted January 10, 2019.

*Corresponding authors: songjiale@glmc.edu.cn and kunypark@cha .ac.kr
}

LP-KSFY02 effectively upregulated protein expression of SOD1, SOD2, CAT, GSH1, and GSH2 in mouse liver and spleen tissues. Therefore, LP-KSFY02 can effectively prevent D-galactose-induced oxidative aging in mice. Its efficacy was superior to that of Lactobacillus delbrueckii ssp. bulgaricus (LDSB) and vitamin $\mathrm{C}$, which are commonly used in the medical field as antioxidants. Thus, LP-KSFY02 is a high-quality strain with probiotic potential.

Key words: Lactobacillus plantarum, superoxide dismutase, D-galactose, mRNA expression, protein expression

\section{INTRODUCTION}

Xinjiang is located in the Eurasian hinterland and is the largest provincial administrative region in China's land mass. Being distant from the ocean, Xinjiang has a distinct temperate continental climate. Yogurt from Xinjiang, China, is a naturally fermented dairy product that is popular among the Uighurs indigenous to the region and has been consumed by local people as a homemade beverage for more than 10 centuries (Xing et al., 2016). Xinjiang yogurt exhibits a considerably higher nutritional value than fresh cow or sheep milk and it contains various compounds, including lactic acid, lactose, amino acids, minerals, vitamins, and enzymes. The proteins contained in Xinjiang yogurt possess a higher physiological value than those in rice, white flour, and meat (He et al., 2015). The probiotics in Xinjiang yogurt enhance immunity by regulating intestinal flora, affect the health of other organs, and have digestion-promoting effects and a preventive effect on hypertension and coronary heart disease (Sun et al., 2006). The whey contained in the yogurt can suppress cholesterol levels and provide health benefits (antioxidant and hypolipidemic effects). Naturally fermented Xinjiang yogurt contains abundant natural lactic acid 
bacteria $(\mathbf{L A B})$, which play a key role in formation of the yogurt flavor and quality (Zhao et al., 2012). Lactic acid bacteria are also probiotics, with numerous physiological activities for human health (Tuo and Yu, 2012; Yang et al., 2015).

Studies have confirmed that LAB perform many important physiological functions in the human body, including maintaining the balance of human microecology. They can improve food digestibility and utilization rates in the gastrointestinal tract, reduce serum cholesterol levels, control toxins in the body, inhibit the growth and reproduction of spoilage bacteria and the generation of spoilage products in the intestines, produce nutrients, and stimulate tissue development. Thus, LAB affect nutritional status, physiological function, cellular infection, drug effects, toxic reactions, immune responses, tumorigenesis, and other emergency responses in the body (Chen et al., 2017, 2018b; Wei et al., 2018). In particular, Lactobacillus spp. in yogurt can inhibit and eliminate spoilage bacteria, such as Salmonella typhi, Shigella flexneri, and Staphylococcus spp., in the intestines and thereby help improve distribution of the intestinal flora, inhibit toxin production by spoilage bacteria, enhance intestinal function, promote nutrient absorption, and prevent premature aging (Chen et al., 2018b). A decrease in the number of LAB in the body can affect health. Based on their special physiological activities, LAB have been widely used in food, medicine, and other fields (Chen et al., 2017, 2018a,b).

Aging is a spontaneous and inevitable process in living organisms, which gradually show signs of decline in function, adaptability, and immunity. Aging is closely related to numerous diseases, including hypertension, type 2 diabetes, atherosclerosis, and senile dementia, which can be alleviated by delaying aging (Buford, 2016; Kitada et al., 2016; Chard et al., 2017). Currently, D-galactose is recognized as an aging-inducing agent, and aging animal models constructed using Dgalactose are similar to the natural aging process. A small amount of D-galactose in the normal body can be converted into glucose, which participates in metabolism, whereas a large amount of D-galactose causes cell metabolic disorder and changes oxidase activity in tissue cells. These effects subsequently generate large numbers of superoxide anions and oxidation products, the latter of which lead to structural and functional damage of biological macromolecules and ultimately to cellular aging (Li et al., 2016). Antioxidant substances whose antioxidant and anti-aging effects have been verified through the oxidative aging model established by D-galactose have been applied for development of antioxidant and anti-aging health products.
In this study, a new strain of LAB was isolated from yogurt from Xinjiang, China, and named Lactobacillus plantarum KSFY02. We administered the strain to mice following D-galactose-induced oxidative aging and determined its preventive effect on oxidative aging by analyzing mouse serum and tissues to lay the theoretical basis for further in-depth human research and industrial development.

\section{MATERIALS AND METHODS}

\section{Microbial Strain}

A new LAB strain was isolated from yogurt from Xinjiang, China, by our research group; it was named Lactobacillus plantarum KSFY02 and preserved in the China General Microbiological Culture Collection center (CGMCC, Beijing, China; preservation number: CGMCC 15655). Lactobacillus delbrueckii ssp. bulgaricus was also from CGMCC (CGMCC 1.2717).

\section{Oxidative Aging Experiment in Animals}

Kunming mice are a type of outbred mice derived from Swiss mice. After feeding and adaptation to the environment for $1 \mathrm{wk}$, fifty 6 -wk-old specific-pathogenfree (SPF) Kunming mice (25 males and 25 females) were purchased from Chongqing Medical University (Chongqing, China) and evenly divided into the following 5 groups: normal (healthy) group, control (oxidative aging) group, L. delbrueckii ssp. bulgaricus gavage group (LDSB group), L. plantarum KSFY02 gavage group (LP-KSFY02), and vitamin C gavage group (Vc). Each group included 10 mice (5 males and 5 females). During the first $4 \mathrm{wk}$, no treatment was administered in the normal and control groups. The mice in the LDSB and LP-KSFY02 groups were administered LDSB and LP-KSFY02, respectively, at a concentration of $1.0 \times$ $10^{9} \mathrm{cfu} / \mathrm{kg}$ of BW daily by gavage. The mice in the $\mathrm{Vc}$ group were administered vitamin $\mathrm{C}$ at a concentration of $200 \mathrm{mg} / \mathrm{kg}$ of BW daily by gavage. After $4 \mathrm{wk}$, the mice in the control, LDSB, LP-KSFY02, and Vc groups were intraperitoneally injected with D-galactose $(120 \mathrm{mg} / \mathrm{kg}$ of BW) for $6 \mathrm{wk}$. During the D-galactose injections, the mice in the LB, LP-KSFY02, and Vc groups continued to be administered LB, LP-KSFY02, and $\mathrm{Vc}$, respectively, at the previous concentrations by gavage for $6 \mathrm{wk}$. Subsequently, all mice were fasted for $24 \mathrm{~h}$ and then killed by cervical dislocation (Tang and He, 2013; Khan et al., 2017). Cardiac blood and liver samples were collected for subsequent experiments. The thymic, cerebral, cardiac, liver, spleen, and kidney 
indices were determined; organ index was calculated as the organ mass $(\mathrm{g}) /$ mouse body mass $(\mathrm{kg}) \times 100$. The study was approved by the Ethics Committee of Chongqing Medical University (no. SYXK 2018-0003).

\section{Contents of Nitric Oxide, Malondialdehyde, and Glutathione and Activities of Superoxide Dismutase and Glutathione Peroxidase in Serum and Liver}

The obtained blood was centrifuged at $4,884 \times g$ for $10 \mathrm{~min}$ at $25^{\circ} \mathrm{C}$, and the supernatant was collected. The contents of nitric oxide (NO), malondialdehyde (MDA), glutathione (GSH), and activities of superoxide dismutase (SOD) and glutathione peroxidase (GSH-Px) in mouse serum were determined according to the kit instructions (Nanjing Jiancheng Bioengineering Institute, Nanjing City, China) by the Thermo Varioskan LUX multifunctional enzyme marker (Thermo Fisher Scientific, Waltham, MA). A 10\% mouse liver homogenate was prepared and centrifuged at 4,884 $\times g$ for $10 \mathrm{~min}$ at $25^{\circ} \mathrm{C}$, and the supernatant was collected to determine the the NO, MDA, SOD, GSH-Px, and GSH in liver tissue according to the kit instructions (Nanjing Jiancheng Bioengineering Institute).

\section{Pathological Observation of Skin, Liver, and Spleen Tissues}

Mouse skin, liver, and spleen tissues, each with an area of approximately $0.5 \mathrm{~cm}^{2}$, were collected and fixed in $10 \%$ formalin solution for $48 \mathrm{~h}$. The tissues were dehydrated, cleared, embedded in wax, and cut, followed by hematoxylin and eosin (H\&E) staining. Morphological changes in the tissues were examined under a light microscope (BX43, Olympus, Tokyo, Japan).

\section{Quantitative PCR Assay}

The liver and spleen tissues of the mice were homogenized, and then RNAzol (Thermo Fisher Scientific Inc.) was used to extract total RNA from the tissues; the extracted RNA was diluted to a total concentration of $1 \mu \mathrm{g} / \mu \mathrm{L}$. Then, $5 \mu \mathrm{L}$ of the diluted total RNA solution was applied for reverse transcription according to the reverse transcription kit method to obtain a cDNA template. After $2 \mu \mathrm{L}$ of cDNA template was mixed with $10 \mu \mathrm{L}$ of SYBR Green PCR Master Mix and $1 \mu \mathrm{L}$ of upstream and downstream primers (Thermo Fisher Scientific Inc.; Table 1), the reaction proceeded at $95^{\circ} \mathrm{C}$ for $60 \mathrm{~s}$, followed by 40 cycles of $95^{\circ} \mathrm{C}$ for $15 \mathrm{~s}, 55^{\circ} \mathrm{C}$ for $30 \mathrm{~s}$, and $72^{\circ} \mathrm{C}$ for $35 \mathrm{~s}$. Finally, detection was carried out at $95^{\circ} \mathrm{C}$ for $30 \mathrm{~s}$ and at $55^{\circ} \mathrm{C}$ for $35 \mathrm{~s}$ using glyceraldehyde-3-phosphate dehydrogenase (Gapdh) as the internal reference (StepOnePlus, Thermo Fisher Scientific Inc.). The $2^{-\Delta \Delta \mathrm{Ct}}$ method was used to calculate relative gene expression (Manini, 2010).

\section{Western Blot Analysis}

A total of $100 \mathrm{mg}$ of liver and spleen tissue samples was homogenized with $1 \mathrm{~mL}$ of radioimmunoprecipitation assay buffer and $10 \mu \mathrm{L}$ of phenylmethylsulfonyl fluoride (Thermo Fisher Scientific Inc.). Then, the sample was centrifuged at $9,982 \times g$ for $4 \mathrm{~min}$ at $25^{\circ} \mathrm{C}$. The intermediate protein layer solution was collected, and a bicinchoninic acid (BCA) protein quantification kit (Thermo Fisher Scientific Inc.) was used for protein quantification. The samples from each group were diluted to $50 \mu \mathrm{g} / \mathrm{mL}$; then, the diluted protein was mixed with sample buffer at a 4:1 ratio, and the mixture was heated at $100^{\circ} \mathrm{C}$ for $5 \mathrm{~min}$. Subsequently, acrylamide, resolving buffer, stacking buffer, distilled water, $10 \%$ ammonium persulfate, and tetramethylethylenediamine were mixed in appropriate proportions to prepare the separating and stacking gels for SDS-PAGE (Thermo Fisher Scientific Inc.) and poured into gel running plates for future use. The stained protein ladder and sample were separately loaded into the sample wells of the gel

Table 1. Quantitative PCR primer sequences

\begin{tabular}{|c|c|}
\hline Gene $^{1}$ & Sequence \\
\hline \multirow[t]{2}{*}{ Nos1 } & Forward: 5'-ACGGCAAACTGCACAAAGC-3' \\
\hline & Reverse: 5'-CGTTCTCTGAATACGGGTTGTTG-3' \\
\hline \multirow[t]{2}{*}{ Nos3 } & Forward: 5'-TCAGCCATCACAGTGTTCCC-3' \\
\hline & Reverse: 5'-ATAGCCCGCATAGCGTATCAG-3' \\
\hline \multirow[t]{2}{*}{ Nos2 } & Forward: 5'-GTTCTCAGCCCAACAATACAAGA-3' \\
\hline & Reverse: 5'-GTGGACGGGTCGATGTCAC-3' \\
\hline \multirow[t]{2}{*}{ Sod1 } & Forward: 5'-AACCAGTTGTGTTGTCAGGAC-3' \\
\hline & Reverse: 5'-CCACCATGTTTCTTAGAGTGAGG-3' \\
\hline \multirow[t]{2}{*}{ Sod2 } & Forward: 5'-CAGACCTGCCTTACGACTATGG-3' \\
\hline & Reverse: 5'-CTCGGTGGCGTTGAGATTGTT-3' \\
\hline \multirow[t]{2}{*}{ Cat } & Forward: 5'-GGAGGCGGGAACCCAATAG-3' \\
\hline & Reverse: 5'-GTGTGCCATCTCGTCAGTGAA-3' \\
\hline \multirow[t]{2}{*}{ Hmox1 } & Forward: 5'-ACAGATGGCGTCACTTCG-3' \\
\hline & Reverse: 5'-TGAGGACCCACTGGAGGA-3' \\
\hline \multirow[t]{2}{*}{ Nfe2l2 } & Forward: 5'-CAGTGCTCCTATGCGTGAA-3' \\
\hline & Reverse: 5'-GCGGCTTGAATGTTTGTC-3' \\
\hline \multirow[t]{2}{*}{ Gclm } & Forward: 5'-GCACATCTACCACGCAGTCA-3' \\
\hline & Reverse: 5'-CAGAGTCTCAAGAACATCGCC-3' \\
\hline \multirow[t]{2}{*}{ Nqo1 } & Forward: 5'-CTTTAGGGTCGTCTTGGC-3' \\
\hline & Reverse: 5'-CAATCAGGGCTCTTCTCG-3' \\
\hline \multirow[t]{2}{*}{ Gapdh } & Forward: 5'-AGGTCGGTGTGAACGGATTTG-3' \\
\hline & Reverse: 5'-GGGGTCGTTGATGGCAACA-3' \\
\hline
\end{tabular}

${ }^{1}$ Nos1 $=$ neuronal nitric oxide synthase Nos3 $=$ endothelial nitric oxide synthase; Nos2 = inducible nitric oxide synthase; Sod1 = cuprozinc-superoxide dismutase; Sod2 = manganese superoxide dismutase; Cat = catalase Hmox1 = heme oxygenase- $1 ;$ Nfe2l2 = nuclear factorerythroid 2 related factor $2 ; G c l m=\gamma$-glutamylcysteine synthetase; Nqo1 $=\mathrm{NAD}(\mathrm{P}) \mathrm{H}$ dehydrogenase [quinone] 1. 
running plates, and the protein-loaded SDS-PAGE gel was subjected to $50 \mathrm{~min}$ of vertical gel electrophoresis. The polyvinylidene difluoride (PVDF) membrane (Thermo Fisher Scientific Inc.) was activated by methanol for 1 min to conduct membrane transfer, and then the membrane was blocked with $5 \%$ skim milk in Trisbuffered saline with Tween 20 (TBST) solution for $1 \mathrm{~h}$. After blocking, the membrane was washed with TBST and incubated with primary antibody (Thermo Fisher Scientific Inc.) at $25^{\circ} \mathrm{C}$ for $2 \mathrm{~h}$; the membrane was then washed with TBST and incubated with secondary antibody (Thermo Fisher Scientific Inc.) at $25^{\circ} \mathrm{C}$ for $1 \mathrm{~h}$. Finally, SuperSignal West Pico PLUS (Thermo Fisher Scientific Inc.) was added to cover the membrane completely and it was placed in an iBright FL1000 imaging system for observation (Thermo Fisher Scientific Inc.; Tessari, 2015).

\section{Statistical Analysis}

The results of serum and tissue measurements were the averages of 3 independent experiments. The SAS statistical software (version 9.1; SAS Institute Inc., Cary, NC) was used for data analysis, and one-way ANOVA was used to determine statistical significance.

\section{RESULTS}

\section{Mouse Organ Indices}

As shown in Table 2, the thymic, cerebral, cardiac, liver, spleen, and kidney indices of the control group were decreased significantly compared with those of the normal group $(P<0.05)$, indicating that intraperitoneal injection of D-galactose caused atrophy of the thymus, brain, heart, liver, spleen, and kidney tissues. Compared with those of the control group mice (Dgalactose-induced oxidative aging), the indices of mice in the LAB- and vitamin C-treated groups increased significantly, indicating that the degree of tissue atrophy in these 3 groups was lower than that of the control group, with LP-KSFY02 showing the strongest effect on tissue atrophy. Therefore, LP-KSFY02 could effectively inhibit the decrease in organ indices caused by oxidative aging and alleviate body tissue atrophy caused by D-galactose.

\section{Levels of NO and MDA and Activities of SOD, GSH-PX, and GSH}

As shown in Tables 3, 4, and 5, the control group mice exhibited the highest levels of $\mathrm{NO}$ and MDA and the lowest activities of SOD, GSH-Px, and GSH in serum, liver, and spleen. Following treatment with LDSB, LP-KSFY02, and Vc, levels of NO and MDA decreased in the oxidative aging mice and activities of SOD, GSH-Px, and GSH were increased. In particular, the levels of NO and MDA and activities of SOD, GSH$\mathrm{Px}$, and GSH in mice treated with LP-KSFY02 were closest to those of the normal group, and the effect of LP-KSFY02 on inhibiting the effects of oxidative aging, as measured by NO, SOD, GSH-Px, GSH, and MDA, was greater than those of LDSB and Vc.

\section{Pathological Observations of Mouse Tissues}

The skin from the D-galactose-induced aging model mice was observed under a light microscope, as shown in Figure 1. The epidermis structure of the normal (untreated) group was clear and intact, the collagen fiber content in the dermis was high, the boundary between the dermis and epidermis was clear, and the number of lipid vacuoles was normal. Compared with mice of the normal group, mice in the control group had a decreased collagen fiber content and increased numbers of lipid vacuoles, with endosmosis occurring in the dermis and a blurred boundary between the dermis and epidermis. Compared with mice of the control group, mice in the Vc, LDSB, and LP-KSFY02 groups had fewer lipid vacuoles, effectively alleviated endosmosis, and an apparent boundary between the epidermis and dermis. The results showed that LDSB and LP-KSFY02 allevi-

Table 2. Organ indices of mice in each group ${ }^{1}$

\begin{tabular}{|c|c|c|c|c|c|c|}
\hline Group $^{2}$ & Thymus & Brain & Cardiac & Liver & Spleen & Kidney \\
\hline Normal & $0.29 \pm 0.02^{\mathrm{a}}$ & $2.03 \pm 0.05^{\mathrm{a}}$ & $5.11 \pm 0.07^{\mathrm{a}}$ & $39.38 \pm 0.47^{\mathrm{a}}$ & $4.28 \pm 0.15^{\mathrm{a}}$ & $13.02 \pm 0.25^{\mathrm{a}}$ \\
\hline Control & $0.15 \pm 0.02^{\mathrm{d}}$ & $1.05 \pm 0.04^{\mathrm{e}}$ & $4.02 \pm 0.04^{\mathrm{e}}$ & $30.71 \pm 0.39^{\mathrm{e}}$ & $2.45 \pm 0.17^{\mathrm{d}}$ & $9.03 \pm 0.15^{\mathrm{e}}$ \\
\hline LDSB & $0.19 \pm 0.03^{\mathrm{c}}$ & $1.31 \pm 0.05^{\mathrm{d}}$ & $4.29 \pm 0.05^{\mathrm{d}}$ & $34.02 \pm 0.41^{\mathrm{d}}$ & $3.32 \pm 0.16^{\mathrm{c}}$ & $10.11 \pm 0.23^{\mathrm{d}}$ \\
\hline LP-KSFY02 & $0.25 \pm 0.02^{\mathrm{b}}$ & $1.86 \pm 0.03^{\mathrm{b}}$ & $4.88 \pm 0.05^{\mathrm{b}}$ & $37.11 \pm 0.44^{\mathrm{b}}$ & $3.86 \pm 0.12^{\mathrm{b}}$ & $12.68 \pm 0.19^{\mathrm{b}}$ \\
\hline $\mathrm{Vc}$ & $0.21 \pm 0.02^{\mathrm{c}}$ & $1.62 \pm 0.05^{\mathrm{c}}$ & $4.60 \pm 0.04^{\mathrm{c}}$ & $35.67 \pm 0.37^{\mathrm{c}}$ & $3.52 \pm 0.16^{\mathrm{c}}$ & $11.55 \pm 0.20^{\mathrm{c}}$ \\
\hline
\end{tabular}

${ }^{\mathrm{a}-\mathrm{e}}$ Mean values with different letters within a column are significantly different $(P<0.05)$ according to Duncan's multiple range test.

${ }^{1}$ Values presented are the mean $\pm \mathrm{SD}(\mathrm{n}=10 /$ group). Organ index was calculated as the organ mass $(\mathrm{g}) / \mathrm{mouse}$ body mass $(\mathrm{kg}) \times 100$.

${ }^{2}$ Normal = untreated mice; control = mice treated with D-galactose $(120 \mathrm{mg} / \mathrm{kg}$ of BW $) ;$ LDSB = mice treated with Lactobacillus delbrueckii

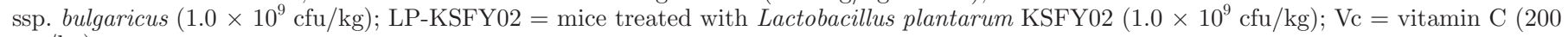
$\mathrm{mg} / \mathrm{kg})$. 
Table 3. Levels or activities of nitric oxide (NO), superoxide dismutase (SOD), glutathione peroxidase (GSH-Px), glutathione (GSH), and malondialdehyde (MDA) in serum of mice ${ }^{1}$

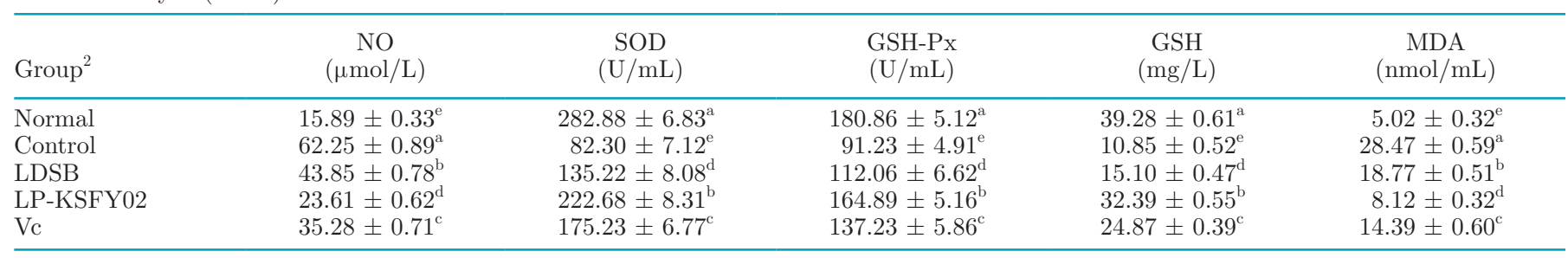

${ }^{a-e}$ Mean values with different letters within a column are significantly different $(P<0.05)$ according to Duncan's multiple range test.

${ }^{1}$ Values presented are the mean $\pm \mathrm{SD}(\mathrm{n}=10$ /group).

${ }^{2}$ Normal $=$ untreated mice; control $=$ mice treated with D-galactose $(120 \mathrm{mg} / \mathrm{kg}$ of BW $) ;$ LDSB $=$ mice treated with Lactobacillus delbrueckii ssp. bulgaricus $\left(1.0 \times 10^{9} \mathrm{cfu} / \mathrm{kg}\right) ; \mathrm{LP}-\mathrm{KSFY} 02=$ mice treated with Lactobacillus plantarum KSFY02 $\left(1.0 \times 10^{9} \mathrm{cfu} / \mathrm{kg}\right) ; \mathrm{Vc}=\mathrm{vitamin} \mathrm{C}(200$ $\mathrm{mg} / \mathrm{kg})$.

ated skin lesions in the D-galactose-induced aging mice. Mice in the LP-KSFY02 group closer to the normal mice than those in LDSB and Vc groups, and thus the efficacy of LP-KSFY02 in preventing skin lesions was better.

Histopathological slices of liver were observed under a microscope, as shown in Figure 2. In the normal group, mouse liver cells showed an orderly arrangement and a regular shape, the size of the liver cells was consistent, the staining was uniform, and no aggregation of inflammatory cells and no obvious lesions were observed. In the control group, the mouse liver cells exhibited a disorderly arrangement with an irregular shape; the boundary appeared blurred, the cells became swollen, and inflammatory infiltration occurred in a large number of cells. Compared with those of the control group, the abnormalities in liver cells from the LDSB, LP-KSFY02, and Vc groups were alleviated to different extents. In particular, in the LP-KSFY02 group, the liver cells were generally orderly arranged, the hepatic cords were relatively regularly arranged, cell infiltration occurred occasionally, the nuclear structure was relatively clear, and the liver cell morphology was closest to that of the normal group. The results showed that LP-KSFY02 alleviated the D-galactose-induced pathological changes in the liver of model aging mice and that the efficacy of LP-KSFY02 was better than that of LDSB or Vc.

Histopathological slices of spleen from the normal group and groups treated with D-galactose are shown in Figure 3. The spleen structure of the normal group was clear and intact, the corticomedullary zone was clear, and the cells were arranged in an orderly manner. In comparison, in the control group, the spleen structure disappeared, the shape was irregular, the red pulp sinus was dilated and filled with a large number of red blood cells, the number of white pulp lymphocytes was reduced, the red pulp cord was narrowed, and the cells were arranged sparsely. In mice treated with LDSB, LP-KSFY02, or Vc, the splenic lesions were comparable with those of the control group. The morphological structure of the spleen was significantly improved, the boundary between the red pulp and white pulp was relatively clear, the germinal center was relatively distinct, and the cells were uniformly arranged; the effect of oxidative aging on the splenic lesions was lowest after LP-KSFY02 treatment. Treatment with LDSB, LP-KSFY02, and Vc can alleviate the spleen tissue lesions in D-galactose-induced oxidative aging model mice. Treatments LDSB and Vc had relatively good ef-

Table 4. Levels or activities of nitric oxide (NO), superoxide dismutase (SOD), glutathione peroxidase (GSH-Px), glutathione (GSH), and malondialdehyde (MDA) in liver of mice ${ }^{1}$

\begin{tabular}{lccccc}
\hline Group $^{2}$ & $\begin{array}{c}\text { NO } \\
(\mu \mathrm{mol} / \mathrm{g} \text { of protein })\end{array}$ & $\begin{array}{c}\text { SOD } \\
(\mathrm{U} / \mathrm{mg} \text { of protein })\end{array}$ & $\begin{array}{c}\text { GSH-Px } \\
(\mathrm{U} / \mathrm{mg} \text { of protein })\end{array}$ & $\begin{array}{c}\text { GSH } \\
(\mathrm{mg} / \mathrm{g} \text { of protein) }\end{array}$ & $\begin{array}{c}\text { MDA } \\
(\mathrm{nmol} / \mathrm{mg} \text { of protein) }\end{array}$ \\
\hline Normal & $3.15 \pm 0.16^{\mathrm{e}}$ & $98.32 \pm 7.83^{\mathrm{a}}$ & $171.20 \pm 8.32^{\mathrm{a}}$ & $8.91 \pm 0.38^{\mathrm{a}}$ & $2.35 \pm 0.26^{\mathrm{e}}$ \\
Control & $9.89 \pm 0.36^{\mathrm{a}}$ & $23.88 \pm 4.65^{\mathrm{e}}$ & $85.14 \pm 4.25^{\mathrm{e}}$ & $2.43 \pm 0.18^{\mathrm{e}}$ & $9.81 \pm 0.33^{\mathrm{a}}$ \\
LDSB & $7.25 \pm 0.31^{\mathrm{b}}$ & $41.05 \pm 4.33^{\mathrm{d}}$ & $105.17 \pm 6.77^{\mathrm{d}}$ & $4.12 \pm 0.22^{\mathrm{d}}$ & $6.71 \pm 0.26^{\mathrm{b}}$ \\
LP-KSFY02 & $4.18 \pm 0.23^{\mathrm{d}}$ & $81.29 \pm 4.91^{\mathrm{b}}$ & $149.23 \pm 6.32^{\mathrm{b}}$ & $7.18 \pm 0.26^{\mathrm{b}}$ & $3.19 \pm 0.15^{\mathrm{d}}$ \\
Vc & $5.82 \pm 0.22^{\mathrm{c}}$ & $62.37 \pm 5.18^{\mathrm{c}}$ & $129.12 \pm 5.36^{\mathrm{c}}$ & $5.47 \pm 0.19^{\mathrm{c}}$ & $5.02 \pm 0.20^{\mathrm{c}}$ \\
\hline
\end{tabular}

${ }^{a-e}$ Mean values with different letters within a column are significantly different $(P<0.05)$ according to Duncan's multiple range test.

${ }^{1}$ Values presented are the mean $\pm \mathrm{SD}(\mathrm{n}=10$ /group).

${ }^{2}$ Normal $=$ untreated mice; control = mice treated with D-galactose $(120 \mathrm{mg} / \mathrm{kg}$ of BW $) ; \mathrm{LDSB}=$ mice treated with Lactobacillus delbrueckii ssp. bulgaricus $\left(1.0 \times 10^{9} \mathrm{cfu} / \mathrm{kg}\right) ; \mathrm{LP}-\mathrm{KSFY} 02=$ mice treated with Lactobacillus plantarum KSFY02 $\left(1.0 \times 10^{9} \mathrm{cfu} / \mathrm{kg}\right) ; \mathrm{Vc}=\mathrm{vitamin} \mathrm{C}(200$ $\mathrm{mg} / \mathrm{kg})$. 
Table 5. Levels or activities of nitric oxide (NO), superoxide dismutase (SOD), glutathione peroxidase (GSH-Px), glutathione (GSH), and malondialdehyde (MDA) in spleen of mice ${ }^{1}$

\begin{tabular}{lccccc}
\hline Group $^{2}$ & $\begin{array}{c}\text { NO } \\
(\mu \text { mol/g of protein })\end{array}$ & $\begin{array}{c}\text { SOD } \\
(\mathrm{U} / \mathrm{mg} \text { of protein })\end{array}$ & $\begin{array}{c}\text { GSH-Px } \\
(\mathrm{U} / \mathrm{mg} \text { of protein })\end{array}$ & $\begin{array}{c}\text { GSH } \\
(\mathrm{mg} / \mathrm{g} \text { of protein) }\end{array}$ & $\begin{array}{c}\text { MDA } \\
(\mathrm{nmol} / \mathrm{mg} \text { of protein) }\end{array}$ \\
\hline Normal & $1.10 \pm 0.14^{\mathrm{e}}$ & $68.97 \pm 3.91^{\mathrm{a}}$ & $119.87 \pm 6.31^{\mathrm{a}}$ & $6.13 \pm 0.54^{\mathrm{a}}$ & $1.12 \pm 0.11^{\mathrm{e}}$ \\
Control & $8.54 \pm 0.31^{\mathrm{a}}$ & $20.85 \pm 2.25^{\mathrm{e}}$ & $45.69 \pm 3.28^{\mathrm{e}}$ & $1.44 \pm 0.31^{\mathrm{e}}$ & $4.74 \pm 0.28^{\mathrm{a}}$ \\
LDSB & $6.02 \pm 0.22^{\mathrm{c}}$ & $40.57 \pm 3.11^{\mathrm{d}}$ & $62.36 \pm 3.72^{\mathrm{d}}$ & $2.91 \pm 0.24^{\mathrm{d}}$ & $3.41 \pm 0.22^{\mathrm{b}}$ \\
LP-KSFY02 & $1.78 \pm 0.25^{\mathrm{d}}$ & $62.39 \pm 2.23^{\mathrm{b}}$ & $99.74 \pm 5.32^{\mathrm{b}}$ & $5.31 \pm 0.19^{\mathrm{b}}$ & $1.43 \pm 0.09^{\mathrm{d}}$ \\
Vc & $3.55 \pm 0.22^{\mathrm{c}}$ & $49.71 \pm 2.84^{\mathrm{c}}$ & $73.54 \pm 4.83^{\mathrm{c}}$ & $4.01 \pm 0.20^{\mathrm{c}}$ & $2.59 \pm 0.14^{\mathrm{c}}$ \\
\hline
\end{tabular}

${ }^{\mathrm{a}-\mathrm{e}}$ Mean values with different letters within a column are significantly different $(P<0.05)$ according to Duncan's multiple range test.

${ }^{1}$ Values presented are the mean $\pm \mathrm{SD}(\mathrm{n}=10$ /group).

${ }^{2}$ Normal $=$ untreated mice; control $=$ mice treated with D-galactose $(120 \mathrm{mg} / \mathrm{kg}$ of BW $) ; \mathrm{LDSB}=$ mice treated with Lactobacillus delbrueckii ssp. bulgaricus $\left(1.0 \times 10^{9} \mathrm{cfu} / \mathrm{kg}\right) ; \mathrm{LP}-\mathrm{KSFY} 02=$ mice treated with Lactobacillus plantarum KSFY02 $\left(1.0 \times 10^{9} \mathrm{cfu} / \mathrm{kg}\right) ; \mathrm{Vc}=\mathrm{vitamin} \mathrm{C}(200$ $\mathrm{mg} / \mathrm{kg})$.

ficacies, but LP-KSFY02 showed the best efficacy, with the mouse spleen after LP-KSFY02 treatment being similar to that of mice in the normal group.

\section{Mouse Liver Tissue-Related mRNA Expression}

Figure 4 shows that the liver tissues of mice from the normal group had the strongest mRNA expression of Nos1, Nos3, Sod1, Sod2, Cat, Hmox1, Nfe2l2, Gclm, and Nqo1 (5.12-, 4.57-, 7.52-, 8.45-, 7.02-, 3.48-, 4.12, 4.39-, and 4.22-fold higher than that of the control group, respectively) and the weakest Nos2 expression (relative to 0.18 multiple of control group). The mRNA expression levels of the above genes in liver in the control group showed the opposite trend to those of the normal group. The mRNA expression levels of Nos1, Nos3, Sod1, Sod2, Cat, Hmox1, Nfe2l2, Gclm, and Nqo1 in liver increased significantly after treatment of the D-galactose-induced aging mice with LDSB (relative to $2.55,2.11,2.97,5.02,3.12,2.01,1.87,2.36$, and 2.32 multiple of control group), LP-KSFY02 (relative to $4.18,4.01,6.33,7.37,6.12,2.87,3.52,3.38$, and 3.65 multiple of control group), and Vc (relative to 3.24 , $2.87,5.71,6.02,4.85,2.41,2.33,3.01$, and 2.89 multiple of control group) compared with those of control mice $(P<0.05)$, whereas expression of Nos2 (relative to 0.72 , 0.29 , and 0.52 multiple of control group) decreased significantly $(P<0.05)$. The efficacy of LP-KSFY02 was significantly higher $(P<0.05)$ than those of LDSB and Vc in affecting mRNA expression.

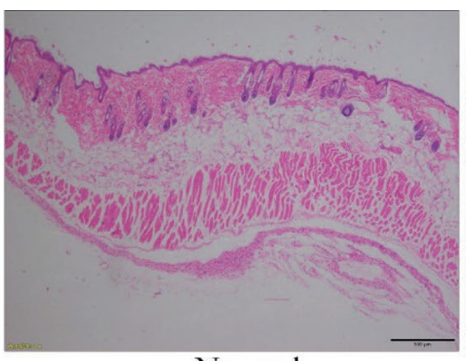

Normal

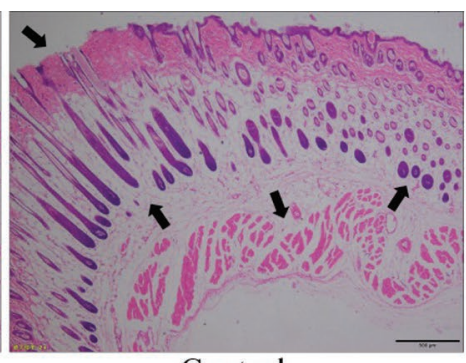

Control

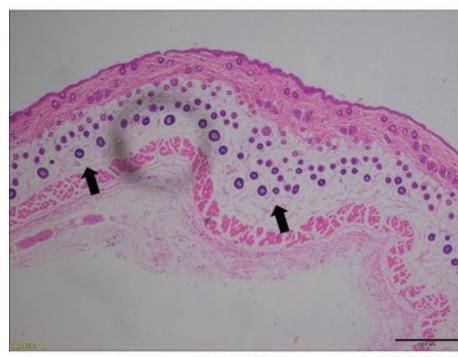

LDSB

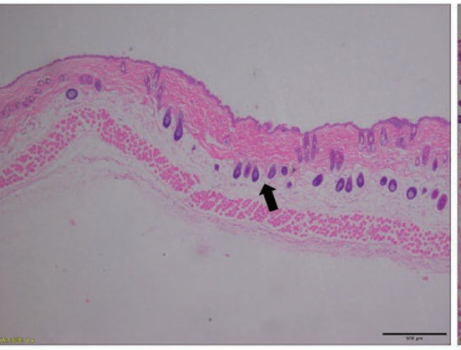

LP-KSFY02

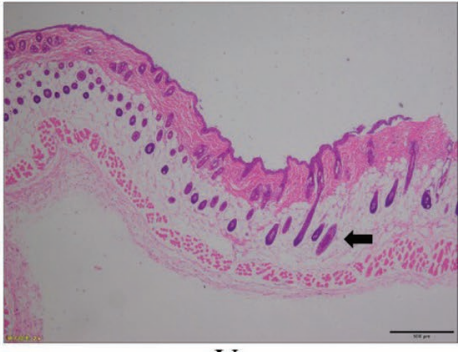

$\mathrm{Vc}$

Figure 1. Hematoxylin and eosin-stained pathological observation of skin tissue in mice. Normal = untreated mice; control = mice treated with D-galactose $\left(120 \mathrm{mg} / \mathrm{kg}\right.$ of BW); LDSB = mice treated with Lactobacillus delbrueckii ssp. bulgaricus $\left(1.0 \times 10^{9} \mathrm{cfu} / \mathrm{kg}\right) ; \mathrm{LP}-\mathrm{KSFY} 02=$ mice treated with Lactobacillus plantarum KSFY02 $\left(1.0 \times 10^{9} \mathrm{cfu} / \mathrm{kg}\right) ; \mathrm{Vc}=$ vitamin C $(200 \mathrm{mg} / \mathrm{kg})$. Magnification $40 \times ;$ scale bar $=200 \mu \mathrm{m}$. Arrows indicate hair follicles. 


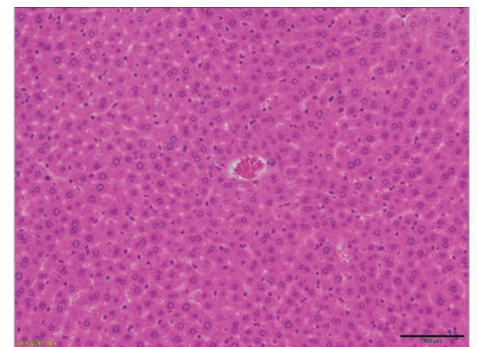

Normal

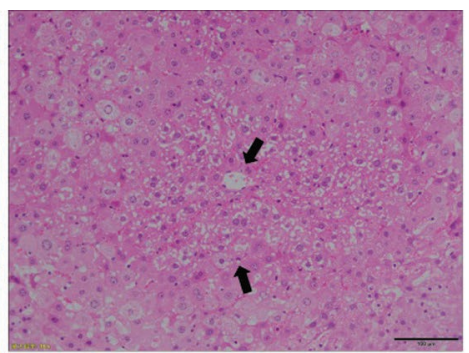

Control

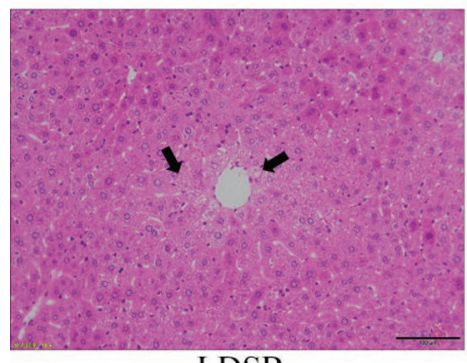

LDSB

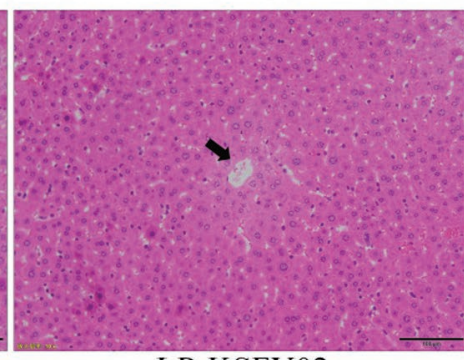

LP-KSFY02

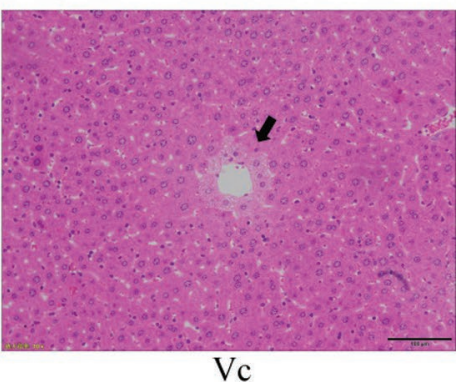

$\mathrm{Vc}$

Figure 2. Hematoxylin and eosin-stained pathological observation of liver tissue in mice. Normal $=$ untreated mice; control $=$ mice treated with D-galactose $(120 \mathrm{mg} / \mathrm{kg}$ of $\mathrm{BW}) ; \mathrm{LDSB}=$ mice treated with Lactobacillus delbrueckii $\mathrm{ssp}$. bulgaricus $\left(1.0 \times 10^{9}\right.$ cfu $\left./ \mathrm{kg}\right) ; \mathrm{LP}-\mathrm{KSFY} 02=$ mice treated with Lactobacillus plantarum KSFY02 $\left(1.0 \times 10^{9} \mathrm{cfu} / \mathrm{kg}\right) ; \mathrm{Vc}=$ vitamin C $(200 \mathrm{mg} / \mathrm{kg})$. Magnification $100 \times$; scale bar $=500 \mu \mathrm{m}$. Arrows indicate hair follicles.

\section{Mouse Spleen Tissue-Related mRNA Expression}

Figure 5 shows that the trend for mRNA expression in the spleen tissues from each group was similar to that in skin and liver. The expression of Nos2 was strongest in spleen of control mice, whereas the expression of other genes was weakest in the control group. After the mice were treated with LP-KSFY02, expression levels in spleen were closest to those in spleen of the normal group. Expression levels in spleen of Nos1, Nos3, Sod1, Sod2, Cat, Hmox1, Nfe2l2, Gclm, and Nqo1 were higher in the LP-KSFY02 group (relative to 3.45, $3.51,5.78,3.67,4.41,3.82,3.62,3.88$, and 2.98 multiple of control group) than in the LDSB group (relative to $2.03,1.88,3.54,1.69,2.65,2.69,2.11,2.12$, and 1.79 multiple of control group) and Vc group (relative to $2.61,2.33,4.35,2.25,3.72,3.17,2.73,3.02$, and 2.23 multiple of control group), whereas expression of Nos2 (relative to 0.35 multiple of control group) was weaker in the LP-KSFY02 group than in the LDSB (relative to 0.71 multiple of control group) and Vc (relative to 0.51 multiple of control group) groups. Thus, treatment with LP-KSFY02 significantly $(P<0.05)$ inhibited the effect of D-galactose on spleen-related gene expression.

\section{Protein Expression in Mouse Liver}

Figure 6 shows that protein expression of SOD1, SOD2, CAT, GSH1, and GSH2 was significantly higher in liver of normal mice $(P<0.05)$ than in liver of mice in the other groups. D-Galactose resulted in a decrease in SOD1, SOD2, CAT, GSH1, and GSH2 protein expression in liver tissue; treatment with LP-KSFY02, LDSB, and Vc significantly $(P<0.05)$ inhibited the decline in expression of these proteins. Treatment with LP-KSFY02 had the strongest effect, with SOD1, SOD2, CAT, GSH1, and GSH2 protein expression in the liver tissue of the D-galactose-treated mice being closest to that in the normal mice.

\section{Protein Expression in Mouse Spleen}

Figure 7 shows that protein expression of SOD1, SOD2, CAT, GSH1, and GSH2 was significantly higher in spleen of normal mice $(P<0.05)$ than in that of the other groups. Following treatment of D-galactoseinduced oxidative aging mice with LP-KSFY02, expression of SOD1, SOD2, CAT, GSH1, and GSH2 was upregulated. The experimental results showed that expression of SOD1, SOD2, CAT, GSH1, and GSH2 in mouse spleen was stronger in the LP-KSFY02 group than in the Vc group, whereas the expression of the above proteins was weakest in the LDSB group.

\section{DISCUSSION}

Organ indices and BW of mice are basic indicators in and an important basis for biomedical research. 


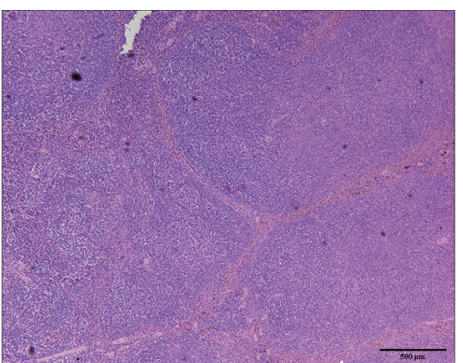

Normal

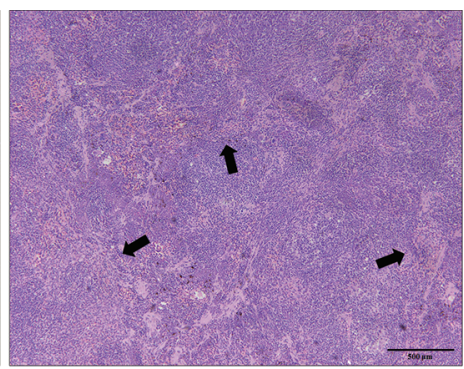

Control

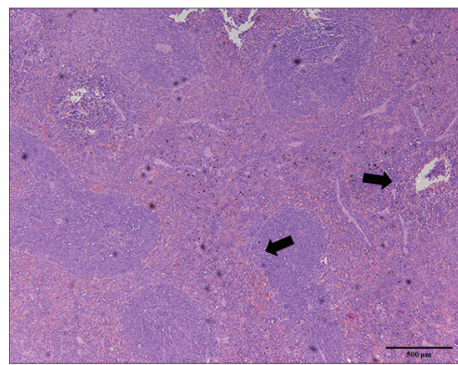

LDSB

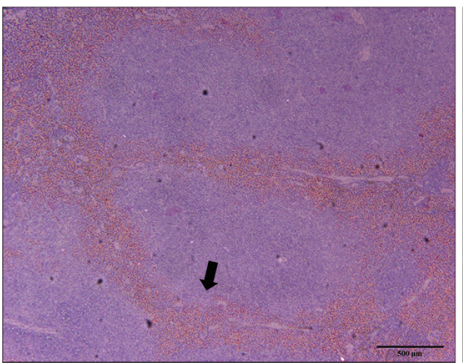

LP-KSFY02

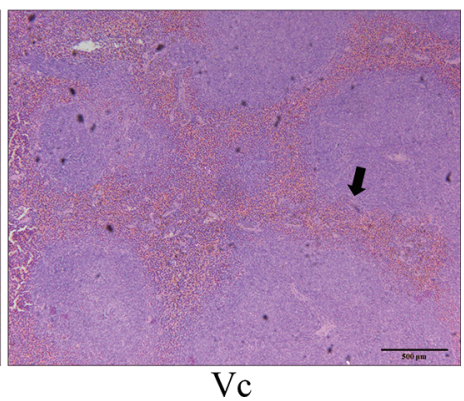

Figure 3. Hematoxylin and eosin-stained pathological observation of spleen tissue in mice. Normal $=$ untreated mice; control $=$ mice treated with D-galactose $\left(120 \mathrm{mg} / \mathrm{kg}\right.$ of BW); LDSB = mice treated with Lactobacillus delbrueckii ssp. bulgaricus $\left(1.0 \times 10^{9} \mathrm{cfu} / \mathrm{kg}\right) ; \mathrm{LP}-\mathrm{KSFY} 02=$ mice treated with Lactobacillus plantarum KSFY02 $\left(1.0 \times 10^{9} \mathrm{cfu} / \mathrm{kg}\right) ; \mathrm{Vc}=$ vitamin $\mathrm{C}(200 \mathrm{mg} / \mathrm{kg})$. Magnification $100 \times ;$ scale bar $=500 \mu \mathrm{m}$.

Changes in organ weight can directly reflect aging of the body. When aging occurs in the body, the thymus and brain show more marked atrophy than other organs. Thymic aging is a leading factor of immune aging, and brain aging is a characteristic change in the aging body (Eroglu et al., 2017). The liver and kidney are metabolic organs in mice, and the decline in their weights directly affects the metabolic capacity of the animal. The liver is also an immune organ in animals (Lee et al., 2001). The spleen is closely related to the cellular immune response in animals and plays an important role in immune mechanisms. A decline in spleen weight indicates the occurrence of atrophy in the organ, which can reduce the immune function of the animal. Therefore, the organ indices of a mouse can directly reflect structural changes and functions of the organs and are important reference values for evaluating whether construction of a mouse model of aging is successful (Bonthius et al., 2015). The results of this study also show that oxidative aging causes a decrease in the organ indices in mice and that LP-KSFY02 could effectively alleviate the decreases in the organ indices caused by D-galactose and allow the organ indices of oxidative aging mice to remain close to those of normal mice.

Pathological observation can evaluate tissues from a morphological perspective to determine pathological changes in the body through changes in histomorphology (Di Meo et al., 2016). Skin, liver, and spleen show distinct changes that reflect some of the characteristic changes that occur in the body due to aging (Ohshima et al., 1999). In this study, observation of skin slices from mice showed significant changes after the induction of aging, with the skin showing age damage. Liver and spleen tissues also showed age damage. The changes in the liver, spleen and skin tissues were caused by aging, and LP-KSFY02 significantly improved this abnormal morphology.

Nitric oxide is produced by oxidation of L-arginine by nitric oxide synthase (NOS). Because NO has a very short half-life, most studies on NO function are based on regulation of NOS activity (Fukai et al., 2000). To date, 3 types of NOS have been found to be involved in the normal physiological or pathological processes of NO (nNOS, eNOS, and iNOS). Nitric oxide is a typical free radical with an unpaired electron on the nitrogen (Wells and Holian, 2007); it can pass through the cell membrane freely and shows strong oxidation activity. Under physiological conditions, NO generally exerts its biological action by acting on soluble guanylate cyclase. However, excess NO can synergize with superoxide anion $\left(\mathrm{O}_{2}{ }^{-}\right)$to cause cellular damage. Nitric oxide can form $\mathrm{ONOO}^{-}$with $\mathrm{O}_{2}^{-}$, inactivate Mn-SOD in the mitochondria, promote the formation of a large number of free radicals, and mediate oxidative aging (Bakır et al., 2016). Under physiological conditions, nNOS and eNOS are expressed and iNOS is not. In particular, nNOS is the most widely distributed and is mainly located in 
central neurons, especially in the cerebellar granule cell and molecular layers. Studies have shown that downregulation of the nNOS protein can inhibit the activity of cerebellar granule cells cultured in vitro in the developmental stage and reduce their survival rate; nNOS can promote the survival of mature cerebellar granule cells, which is most likely related to aging (Fang et al.,
2010). Endothelial NOS can activate soluble guanylate cyclase in vascular smooth muscle cells and increase the intracellular cyclic AMP concentration, thereby expanding blood vessels, inhibiting platelet-leukocyte adhesion and aggregation, and exerting neuroprotective functions (Hosen et al., 2015). Inducible NOS is mainly distributed in macrophages, inflammatory neu-
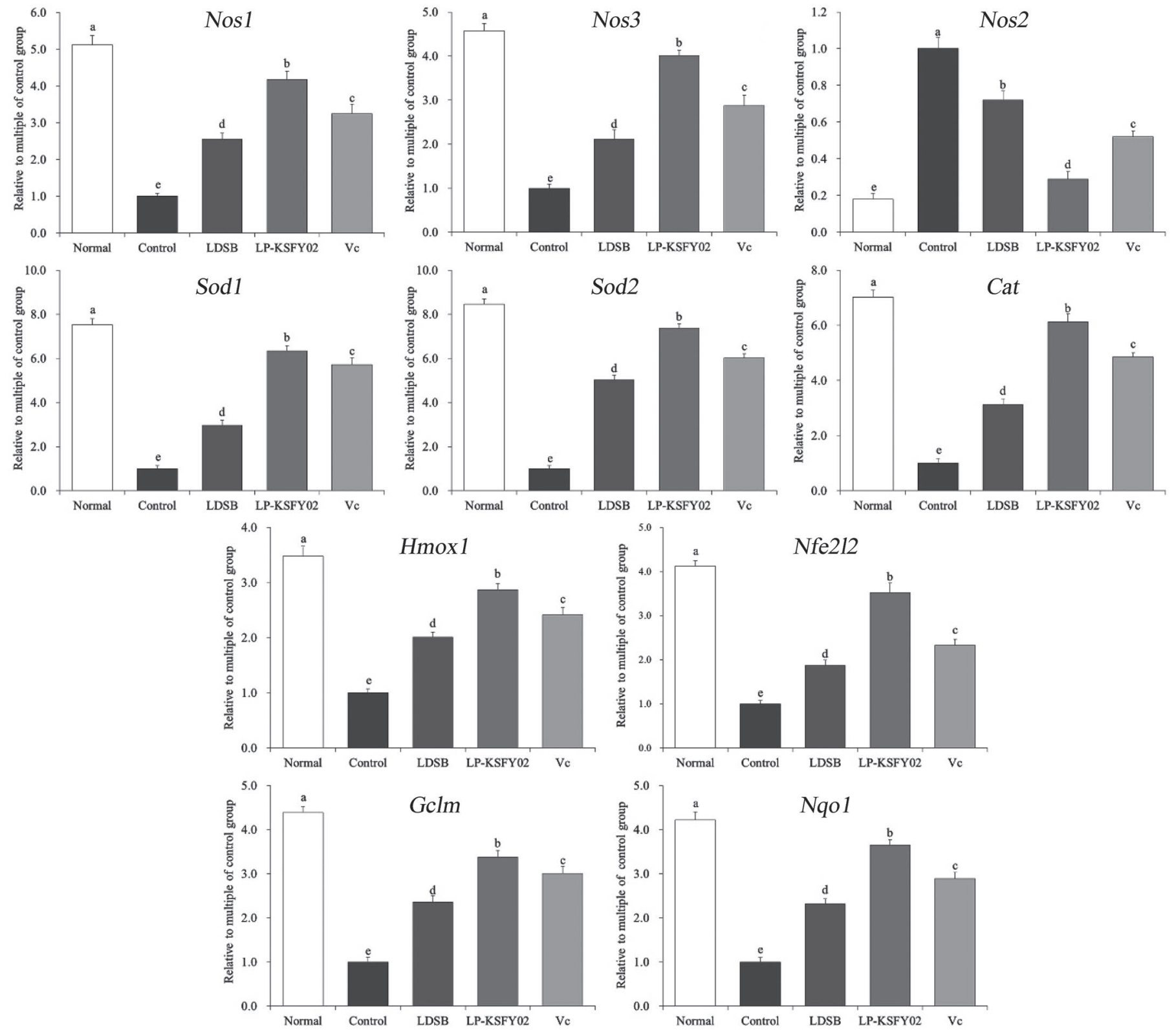

Figure 4. Messenger RNA expression (mean \pm SD) in liver tissue of mice. Normal $=$ untreated mice; control $=$ mice treated with D-galactose $(120 \mathrm{mg} / \mathrm{kg}$ of BW $) ; \mathrm{LDSB}=$ mice treated with Lactobacillus delbrueckii $\mathrm{ssp}$. bulgaricus $\left(1.0 \times 10^{9} \mathrm{cfu} / \mathrm{kg}\right) ; \mathrm{LP}-\mathrm{KSFY} 02=\mathrm{mice}$ treated with Lactobacillus plantarum KSFY02 $\left(1.0 \times 10^{9} \mathrm{cfu} / \mathrm{kg}\right) ; \mathrm{Vc}=$ vitamin C $(200 \mathrm{mg} / \mathrm{kg})$. Nos $1=$ neuronal nitric oxide synthase; Nos3 = endothelial nitric oxide synthase; Nos2 = inducible nitric oxide synthase; Sod1 = cuprozinc-superoxide dismutase; Sod2 = manganese superoxide dismutase; $C a t=$ catalase; $H \operatorname{mox} 1=$ heme oxygenase-1; Nfe2l2 = nuclear factor-erythroid 2 related factor $2 ; G c l m=\gamma$-glutamylcysteine synthetase; $N q o 1$ $=\mathrm{NAD}(\mathrm{P}) \mathrm{H}$ dehydrogenase [quinone] 1 . Mean values with different letters $(\mathrm{a}-\mathrm{e})$ in the same bar are significantly different $(P<0.05)$ according to Duncan's multiple-range test. 
trophils, vascular smooth muscle cells, endothelial cells, microglia, and astrocytes. Once synthesized, NO is continuously produced until the substrate is depleted. An excessive amount of NO production can cause tissue damage via reactive nitrogen and oxidative stress effects (Berndt and Lillig, 2017). The current study confirmed that the oxidative aging caused by D-galactose can cause dysregulation of NOS in the body and that
LP-KSFY02 could inhibit this dysregulation and allow normal mRNA expression of Nos1, Nos3, and Nos2 (encoding nNOS, eNOS, and iNOS, respectively), thereby effectively preventing oxidative aging.

Glutathione peroxidase is an important peroxidedegrading enzyme that is widely present in the body. The main function of GSH-Px is to remove lipid hydroperoxides. A large amount of GSH-Px in tissues can
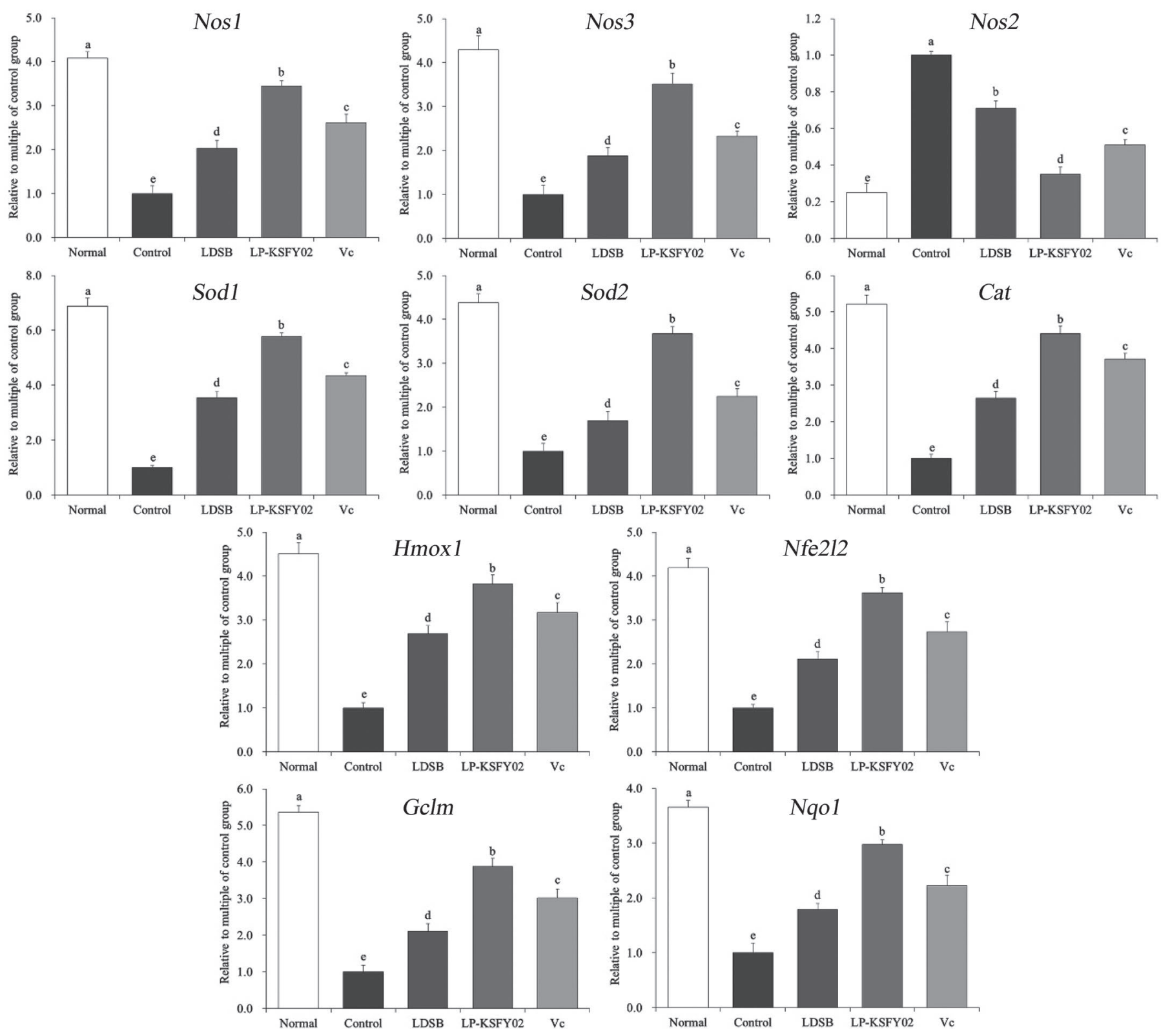

Figure 5. Messenger RNA expression (mean $\pm \mathrm{SD}$ ) in spleen tissue of mice. Normal = untreated mice; control = mice treated with D-galactose $\left(120 \mathrm{mg} / \mathrm{kg}\right.$ of BW); LDSB = mice treated with Lactobacillus delbrueckii $\mathrm{ssp}$. bulgaricus $\left(1.0 \times 10^{9} \mathrm{cfu} / \mathrm{kg}\right) ; \mathrm{LP}-\mathrm{KSFY} 02=\mathrm{mice}$ treated with Lactobacillus plantarum KSFY02 $\left(1.0 \times 10^{9} \mathrm{cfu} / \mathrm{kg}\right) ; \mathrm{Vc}=$ vitamin C $(200 \mathrm{mg} / \mathrm{kg})$. Nos1 = neuronal nitric oxide synthase; Nos3 = endothelial

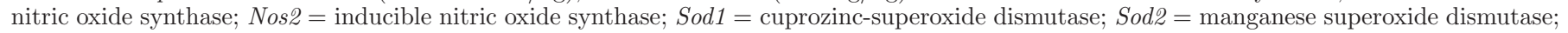

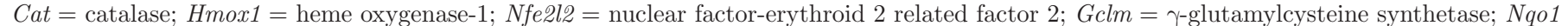

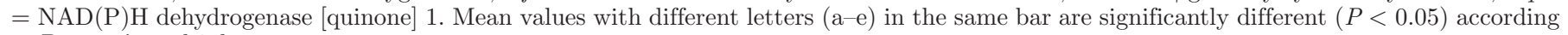
to Duncan's multiple-range test. 
Normal Control LDSB LP-KSFY02 Vc

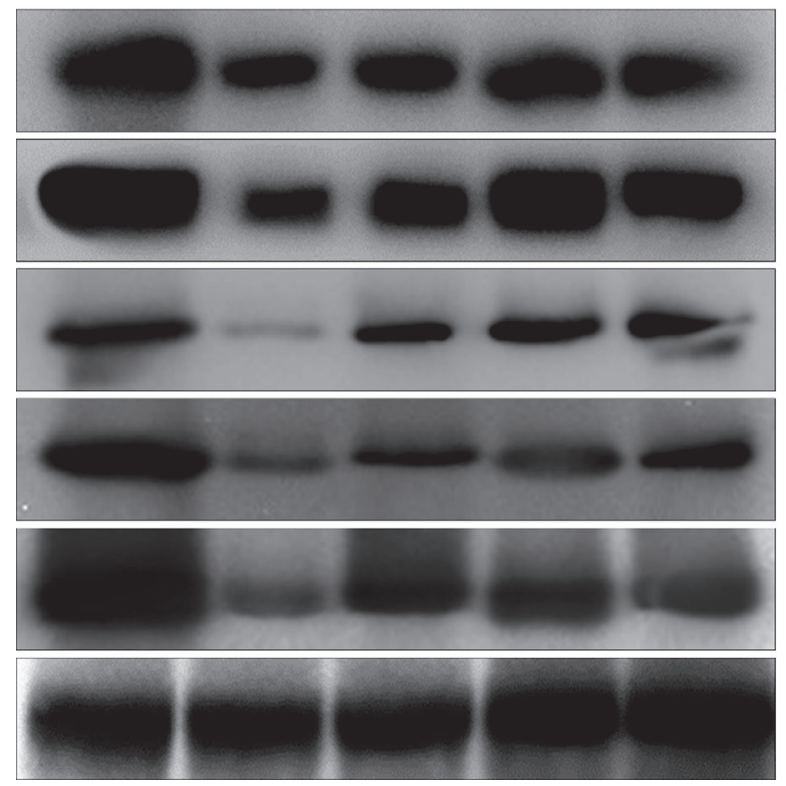

SOD1

SOD2

CAT

GSH1

GSH2

ACTB

Figure 6. Protein expression in liver tissue of mice. Normal $=$ untreated mice; control = mice treated with D-galactose $(120 \mathrm{mg} / \mathrm{kg}$ of BW); LDSB = mice treated with Lactobacillus delbrueckii ssp. bulgaricus $\left(1.0 \times 10^{9} \mathrm{cfu} / \mathrm{kg}\right) ;$ LP-KSFY02 $=$ mice treated with Lactobacillus plantarum KSFY02 $\left(1.0 \times 10^{9} \mathrm{cfu} / \mathrm{kg}\right) ; \mathrm{Vc}=$ vitamin $\mathrm{C}(200 \mathrm{mg} / \mathrm{kg})$. $\mathrm{SOD}=$ superoxide dismutase CAT $=$ catalase; $\mathrm{GSH}=$ glutathione; $\mathrm{ACTB}=\beta$-actin.

Normal Control LDSB LP-KSFY02 Vc

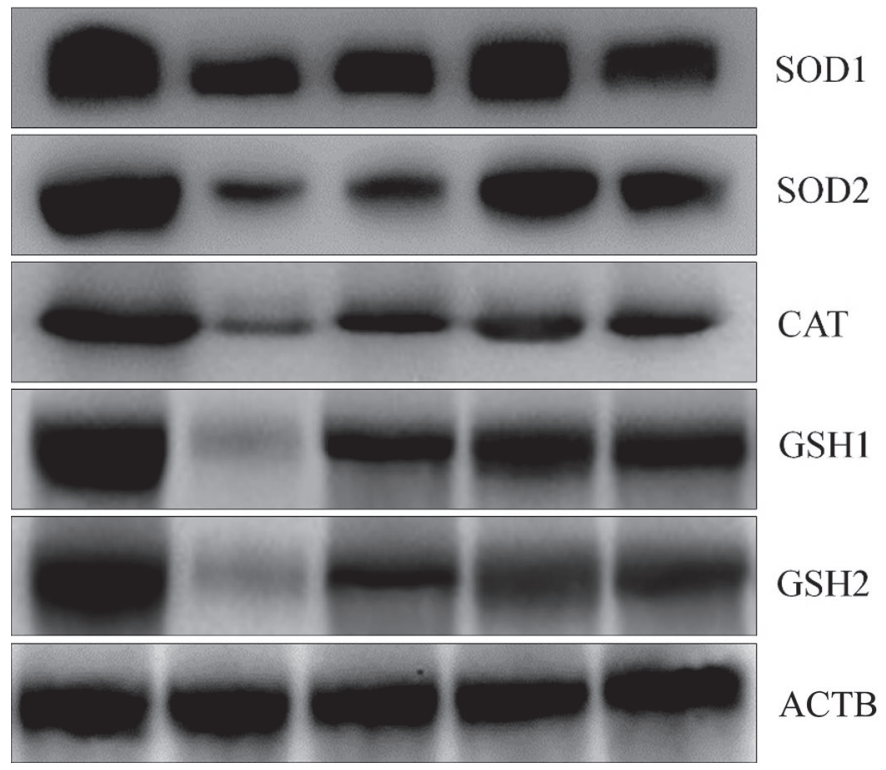

Figure 7. Protein expression in spleen tissue of mice. Normal $=$ untreated mice; control = mice treated with D-galactose $(120 \mathrm{mg} / \mathrm{kg}$ of BW); LDSB = mice treated with Lactobacillus delbrueckii ssp. bulgaricus $\left(1.0 \times 10^{9} \mathrm{cfu} / \mathrm{kg}\right) ; \mathrm{LP}-\mathrm{KSFY} 02=$ mice treated with Lactobacillus plantarum KSFY02 $\left(1.0 \times 10^{9} \mathrm{cfu} / \mathrm{kg}\right) ; \mathrm{Vc}=\operatorname{vitamin} \mathrm{C}(200 \mathrm{mg} / \mathrm{kg})$. $\mathrm{SOD}=$ superoxide dismutase $\mathrm{CAT}=$ catalase; $\mathrm{GSH}=$ glutathione; $\mathrm{ACTB}=\beta$-actin. remove $\mathrm{H}_{2} \mathrm{O}_{2}$ in a timely manner. Under pathophysiological conditions, reactive oxygen species (ROS), such as $\bullet \mathrm{OH}$, may induce lipid peroxidation and not only cause direct damage to the biofilm but also result in extensive damage to the body by reacting with proteins and nucleic acids via lipid hydroperoxides (Wang et al., 2016b). If the ability of GSH-Px to remove lipid hydroperoxides is not affected, the damage to the body can be reduced. Lipid peroxidation is also one of the causes of cellular aging, and prevention of lipid peroxidation can delay the aging process. Thus, GSH-Px plays an important role in preventing oxidation and aging (Iwayama et al., 2017). Through enzymatic and nonenzymatic systems, the body produces oxygen free radicals, which can attack polyunsaturated fatty acids in biofilm, trigger lipid peroxidation, and thus form lipid peroxides, such as MDA. Lipid peroxidation not only converts active oxygen into active chemical agents (i.e., nonradical lipid decomposition products) but also amplifies the action of ROS through chain or branched chain reactions. Oxygen free radicals cause damage to cells through both peroxidation of polyunsaturated fatty acids in biofilms and the decomposition products of lipid hydroperoxides. Therefore, the amount of MDA is measured to reflect the extent of lipid peroxidation in the body and indirectly reflect the extent of cellular damage (Jiang et al., 2017). Our study confirmed that GSH-Px and MDA are directly related to oxidative aging in mice and that LP-KSFY02 can exert its role in inhibiting oxidative aging by increasing the activity of GSH-Px and lowering the amount of MDA.

Glutathione is a highly efficient scavenger of oxygen and nitrogen free radicals and an important factor in maintaining the cellular redox status and homeostasis. It is also involved in immune regulation, intracellular and extracellular matrix remodeling, apoptosis, and mitochondrial respiration and can be used as an intermediate for storing and transferring cysteine. As an antioxidant, GSH reacts with free radicals to form their oxidized forms, thereby protecting tissues and cells from free radical attack and damage (Warner, 1994). In the biosynthetic GSH pathway, glutamate is condensed with cysteine to form $\gamma$-glutamylcysteine with GSH1 as the catalyst. Then, GSH is synthesized from the intermediate products $\gamma$-glutamylcysteine and glycine with GSH2 as the catalyst; GSH1 is a key and rate-limiting enzyme in GSH biosynthesis, although some studies have shown that GSH2 is also rate limiting for GSH synthesis. Regardless, GSH1 and GSH2 are important enzymes for GSH synthesis and provide feedback on GSH activity (Wang et al., 2016a). $\gamma$-Glutamylcysteine synthetase is also a rate-limiting enzyme in GSH synthesis that determines the GSH level in vivo and is an important antioxidant factor. Additionally, the Nrf2 
binding sequence has been shown to be present in the $\gamma$-GCS enhancer and is regulated by Nrf2. Knockdown of Nrf2 can result in decreased expression of the 2 $\gamma$-GCS subunits in mouse fibroblasts and hepatocytes, and Nrf2 shows a highly positive correlation with $\gamma$-GCS mRNA and protein expression (Kosenko et al., 2017). Quinone oxidoreductase 1 (NQO1) is a protective reductase in cells that protects cells from the damages induced by external quinones and oxidative aging. However, in different oxygen environments, the reduced products may be further metabolized or oxidized and thus have different effects. The $N q o 1$ gene acts as a downstream gene of $N r f 2$ (Nfe2l2) and enhanced Nqo1 expression can protect cells after Nrf2 is activated in large amounts (Folbergrová et al., 2013). Regulation of GSH1, GSH2, $\gamma$-GCS, and Nrf2 represents different GSH regulation mechanisms; LP-KSFY02 can regulate GSH1, GSH2, $\gamma$-GCS, and Nrf2, thereby enhancing the GSH levels and preventing oxidative aging.

Superoxide dismutase is an important antioxidant enzyme in the body of living organisms and is widely distributed, including in animals, plants, and microorganisms. It exhibits special physiological activity and is the primary substance for scavenging free radicals in living organisms. The level of SOD in the body serves as an intuitive indicator of aging and death. More than 60 diseases have been confirmed to be caused by oxygen free radicals, and SOD can counteract and prevent the damage caused by oxygen free radicals, repair the damaged cells in time, and allow the cells to recover from the damage. The pressure of modern life, environmental pollution, various radiation exposures, and excessive exercise all cause the formation of a large number of oxygen free radicals; therefore, the role of SOD in the biological antioxidant mechanism becomes increasingly significant (Selvaratnam and Robaire, 2016). Superoxide anion $\left(\mathrm{O}_{2}^{-}\right)$is mainly produced by the body during the process of consuming oxygen and has relatively active chemical properties. Low concentrations of oxygen free radicals are particularly important for maintaining normal life activities, whereas excessively high concentrations destroy certain macromolecular protein structures in the body and cause metabolic disorders in tissues and cells. Superoxide dismutase plays an important role in defense against oxidative stress and can catalyze the disproportionation reaction of $\mathrm{O}_{2}{ }^{-}$and convert harmful $\mathrm{O}_{2}{ }^{-}$into hydrogen peroxide. Although hydrogen peroxide, as active oxygen, is harmful to the body, CAT and peroxidase can immediately break it down into completely harmless water. In this way, the 3 enzymes form a complete antioxidant chain that avoids damage of tissues and cells by ROS (Lei et al., 2017). Superoxide dismutase in the animal body mainly exists in 2 forms: $\mathrm{Cu} / \mathrm{Zn}-\mathrm{SOD}$, which is present in the blood cell cytosol, and Mn-SOD, which is distributed in the mitochondrial matrix; Mn-SOD is considered a key barrier against mitochondrial oxidative aging. As oxygen consumption by the body increases, a large number of oxygen free radicals are formed, which in turn strongly induce Mn-SOD expression. If the produced $\mathrm{O}_{2}{ }^{-}$far exceeds the ability of the body to eliminate it, an imbalance of oxidation and antioxidation is generated, eventually leading to oxidative aging (Sue et al., 2009). Studies have shown that certain atrophic tissue diseases can lead to a decrease in Mn-SOD expression; for instance, atherosclerosis decreases intravascular mRNA expression of Sod1 and Sod2. When oxidative and chemically induced aging occur, the amount of $\mathrm{Cu} / \mathrm{Zn}$-SOD in the body is also substantially reduced (Hong et al., 2017). Catalase is an important antioxidant enzyme in the body that maintains a dynamic balance with SOD. It can decompose hydrogen peroxide into water and oxygen and thus prevent the body from being damaged by harmful substances (Dai et al., 2017). Hydrogen free radicals $\left(\mathrm{OH}^{-}\right)$are the most active ROS in the body and can react with every type of organic matter in the cell, causing the body to age; $\mathrm{OH}^{-}$is decomposed from the precursor hydrogen peroxide, and CAT can reduce the hydrogen peroxide concentration to delay aging (Liu et al., 2017). In this study, LP-KSFY02 regulated oxidative aging of the mouse body by regulating the levels of antioxidants, such as SOD and CAT, and exerting preventive effects on oxidative aging.

Heme oxygenase- 1 is an important antioxidant enzyme that plays a critical role in protecting endogenous and exogenous initial cells against noxious stimuli. The antioxidant activity of $\mathrm{HO}-1$ is related to preventing free heme from participating in the oxidation reaction. Furthermore, HO-1 and its enzymolysis products (bilirubin and $\mathrm{CO}$ ) together exert antioxidant and anti-inflammatory activities, inhibit apoptosis and vasodilation, and improve tissue microcirculation (Zhao et al., 2018). Under normal physiological conditions, HO-1 expression and activity are low. However, under stress conditions, heme, hydrogen peroxide $\left(\mathrm{H}_{2} \mathrm{O}_{2}\right)$, endotoxin, heavy metals, UV radiation, and hyperoxia/ hypoxia can initiate HO-1 expression through Nrf2 and show strong antioxidant activity through scavenging free radicals such as hydrogen peroxide. The Nrf2/HO-1 pathway is widely involved in the protection of tissues and organs, including heart, brain, liver, kidney, and nervous system, from oxidative stress-induced damage, making it one of the most important endogenous protection systems in the body (Zhang et al., 2018). Studies have found that anthocyanin upregulates HO-1 through serine/threonine protein kinase (Akt) and extracellular regulation of protein kinase (ERK1/2)/Nrf2 signaling pathways to eliminate ROS, thereby exerting 
a protective effect on hepatotoxicity. In addition, studies have demonstrated that the active ingredients in some natural plants also inhibit oxidative stress and reduce cytotoxicity through the Nrf2/HO-1 pathway (Li et al., 2018). In our study, LP-KSFY02 showed clear regulation of the Nrf2/HO-1 pathway by inhibiting D-galactose-induced oxidative stress in mice and preventing oxidative aging.

Studies have shown that LAB can decompose and neutralize harmful chemicals in the intestines and thus can clean the intestines and prevent constipation and cell aging, which delay the overall aging process (Vinusha et al., 2018). The newly isolated and identified LAB LP-KSFY02 in this study showed excellent anti-aging effects in a mouse model of oxidative aging. In this study, LP-KSFY02 regulated multiple pathways that caused oxidative aging in mice to prevent D-galactose-induced oxidative aging; as a result, the serum and tissue indices of the oxidative aging mice were close to those of mice in the normal state. In addition, the efficacy of LP-KSFY02 was better than that of commercially used LDSB and it showed good probiotic potential; at the same time, the preventive effect of LP-KSFY02 on oxidative aging was superior to that of vitamin $\mathrm{C}$, which is normally taken into the body.

This in vivo animal experiment preliminarily confirmed that LP-KSFY02 was a high-quality LAB strain that could prevent oxidative aging, laying the theoretical basis for further in-depth development. However, further development and utilization of LP-KSFY02 require human experiments, which are the focus of future research. The specific mechanism underlying the action of LP-KSFY02 in the human body needs to be explored further.

\section{ACKNOWLEDGMENTS}

This research was supported by the Program for Innovation Team Building at Institutions of Higher Education in Chongqing (CXTDX201601040) and the Research Project of Chongqing University of Education (KY2015TBZC), China.

\section{REFERENCES}

Bakır, M., F. Geyikoglu, S. Colak, H. Turkez, T. O. Bakır, and M. Hosseinigouzdagani. 2016. The carvacrol ameliorates acute pancreatitis-induced liver injury via antioxidant response. Cytotechnology 68:1131-1146.

Berndt, C., and C. H. Lillig. 2017. Glutathione, glutaredoxins, and iron. Antioxid. Redox Signal. 27:1235-1251.

Bonthius, D. J., Jr., Z. Winters, B. Karacay, S. L. Bousquet, and D. J. Bonthius. 2015. Importance of genetics in fetal alcohol effects: null mutation of the nNOS gene worsens alcohol-induced cerebellar neuronal losses and behavioral deficits. Neurotoxicology 46:60-72.

Buford, T. W. 2016. Hypertension and aging. Ageing Res. Rev. 26:96111.
Chard, S., B. Harris-Wallace, E. G. Roth, L. M. Girling, R. Rubinstein, A. M. Reese, C. C. Quinn, and J. K. Eckert. 2017. Successful aging among African American older adults with type 2 diabetes. J. Gerontol. B Psychol. Sci. Soc. Sci. 72:319-327.

Chen, X., F. Tan, R. Yi, J. Mu, X. Zhao, and Z. Yang. 2018a. Effects of Lactobacillus on mice with diabetes induced by high-fat diet with streptozotocin (STZ). Appl. Sci. (Basel) 8:1249.

Chen, X., J. Zhang, R. Yi, J. Mu, X. Zhao, and Z. Yang. 2018b. Hepatoprotective effects of Lactobacillus on carbon tetrachlorideinduced acute liver injury in mice. Int. J. Mol. Sci. 19:2212.

Chen, X., X. Zhao, H. Wang, Z. Yang, J. Li, and H. Suo. 2017. Prevent effects of Lactobacillus fermentum HY01 on dextran sulfate sodium-induced colitis in mice. Nutrients 9:545.

Dai, C., L. Lei, B. Li, Y. Lin, X. Xiao, and S. Tang. 2017. Involvement of the activation of Nrf2/HO-1, p38 MAPK signaling pathways and endoplasmic reticulum stress in furazolidone induced cytotoxicity and S phase arrest in human hepatocyte L02 cells: Modulation of curcumin. Toxicol. Mech. Methods 27:165-172.

Di Meo, S., T. T. Reed, P. Venditti, and V. M. Victor. 2016. Role of ROS and RNS sources in physiological and pathological conditions. Oxid. Med. Cell. Longev. 2016:1245049.

Eroglu, E., S. Hallström, H. Bischof, M. Opelt, K. Schmidt, B. Mayer, M. Waldeck-Weiermair, W. F. Graier, and R. Malli. 2017. Realtime visualization of distinct nitric oxide generation of nitric oxide synthase isoforms in single cells. Nitric Oxide 70:59-67.

Fang, W. T., H. J. Li, and L. S. Zhou. 2010. Protective effects of prostaglandin E1 on human umbilical vein endothelial cell injury induced by hydrogen peroxide. Acta Pharmacol. Sin. 31:485-492.

Folbergrová, J., P. Ješina, H. Nůsková, and J. Houštěk. 2013. Antioxidant enzymes in cerebral cortex of immature rats following experimentally-induced seizures: Upregulation of mitochondrial MnSOD (SOD2). Int. J. Dev. Neurosci. 31:123-130.

Fukai, T., M. R. Siegfried, M. Ushio-Fukai, Y. Cheng, G. Kojda, and D. G. Harrison. 2000. Regulation of the vascular extracellular superoxide dismutase by nitric oxide and exercise training. J. Clin. Invest. 105:1631-1639.

He, J., X. Q. Zeng, M. C. Lv, Z. X. Mao, X. L. Wang, and D. D. Pan. 2015. Screening of lactic acid bacteria with high protease and lipase activities from Xinjiang traditional yogurt. Food Science $36: 130-133$.

Hong, C., J. Cao, C. F. Wu, O. Kadioglu, A. Schüffler, U. Kauhl, S. M. Klauck, T. Opatz, E. Thines, N. W. Paul, and T. Efferth. 2017. The Chinese herbal formula Free and Easy Wanderer ameliorates oxidative stress through KEAP1-NRF2/HO-1 pathway. Sci. Rep. $7: 11551$.

Hosen, M. B., M. R. Islam, F. Begum, Y. Kabir, and M. Z. Howlader. 2015. Oxidative stress induced sperm DNA damage, a possible reason for male infertility. Iran. J. Reprod. Med. 13:525-532.

Iwayama, K., A. Kusakabe, K. Ohtsu, T. Nawano, R. Tatsunami, K. I. Ohtaki, Y. Tampo, and N. Hayase. 2017. Long-term treatment of clarithromycin at a low concentration improves hydrogen peroxide-induced oxidant/antioxidant imbalance in human small airway epithelial cells by increasing Nrf2 mRNA expression. BMC Pharmacol. Toxicol. 18:15.

Jiang, X. P., J. Y. Tang, Z. Xu, P. Han, Z. Q. Qin, C. D. Yang, S. Q. Wang, M. Tang, W. Wang, C. Qin, Y. Xu, B. X. Shen, W. M. Zhou, and W. Zhang. 2017. Sulforaphane attenuates diN-butylphthalate-induced reproductive damage in pubertal mice: Involvement of the Nrf2-antioxidant system. Environ. Toxicol. 32:1908-1917.

Khan, S. S., B. D. Singer, and D. E. Vaughan. 2017. Molecular and physiological manifestations and measurement of aging in humans. Aging Cell 16:624-633.

Kitada, M., Y. Ogura, and D. Koya. 2016. The protective role of Sirt1 in vascular tissue: Its relationship to vascular aging and atherosclerosis. Aging (Albany NY) 8:2290-2307.

Kosenko, E. A., L. A. Tikhonova, G. A. Alilova, C. Montoliu, G. E. Barreto, G. Aliev, and Y. G. Kaminsky. 2017. Portacaval shunting causes differential mitochondrial superoxide production in brain regions. Free Radic. Biol. Med. 113:109-118. 
Lee, M. H., D. H. Hyun, P. Jenner, and B. Halliwell. 2001. Effect of proteasome inhibition on cellular oxidative damage, antioxidant defences and nitric oxide production. J. Neurochem. 78:32-41.

Lei, L., Y. Chen, L. Ou, Y. Xu, and X. Yu. 2017. Aqueous root extract of Asparagus cochinchinensis (Lour.) Merr. has antioxidant activity in D-galactose-induced aging mice. BMC Complement. Altern. Med. 17:469.

Li, G. J., J. Wang, Y. J. Cheng, X. Tan, Y. L. Zhai, Q. Wang, F. J. Gao, G. L. Liu, X. Zhao, and H. Wang. 2018. Prophylactic effects of polymethoxyflavone-rich orange peel oil on $\mathrm{N}^{\omega}$-Nitro-L-arginineinduced hypertensive rats. Appl. Sci. (Basel) 8:752.

Li, L., M. Xu, B. Shen, M. Li, Q. Gao, and S. G. Wei. 2016. Moderate exercise prevents neurodegeneration in D-galactose-induced aging mice. Neural Regen. Res. 11:807-815.

Liu, S. Y., J. Xiao, and H. Y. Suo. 2017. Screening and identification of resistant lactobacillus in traditional pickles. Food Machinery $7: 26-30$.

Manini, T. M. 2010. Energy expenditure and aging. Ageing Res. Rev. $9: 1$.

Ohshima, T., R. Schiffmann, G. J. Murray, J. Kopp, J. M. Quirk, S. Stahl, C. C. Chan, P. Zerfas, J. H. Tao-Cheng, J. M. Ward, R. O. Brady, and A. B. Kulkarni. 1999. Aging accentuates and bone marrow transplantation ameliorates metabolic defects in Fabry disease mice. Proc. Natl. Acad. Sci. USA 96:6423-6427.

Selvaratnam, J. S., and B. Robaire. 2016. Effects of aging and oxidative stress on spermatozoa of superoxide-dismutase 1- and catalase-null mice. Biol. Reprod. 95:60.

Sue, Y. M., C. F. Cheng, C. C. Chang, Y. Chou, C. H. Chen, and S. H. Juan. 2009. Antioxidation and anti-inflammation by haem oxygenase-1 contribute to protection by tetramethylpyrazine against gentamicin-induced apoptosis in murine renal tubular cells. Nephrol. Dial. Transplant. 24:769-777.

Sun, T. S., H. X. Liu, H. J. Ni, Y. Jin, and H. P. Zhang. 2006. Isolation and identification of lactic acid bacteria in Hogormag, a traditional fermented camel milk product. Zhongguo Rupin Gongye 34:4-7.

Tang, T., and B. He. 2013. Treatment of D-galactose induced mouse aging with Lycium barbarum polysaccharides and its mechanism study. Afr. J. Tradit. Complement. Altern. Med. 10:12-17.

Tessari, P. 2015. Nitric oxide in the normal kidney and in patients with diabetic nephropathy. J. Nephrol. 28:257-268.
Tuo, N., and H. Y. Yu. 2012. Advance of ethanol-induced gastric mucosa injury. J. Chin. Inst. Food Sci. Technol. 12:161-166.

Vinusha, K. S., K. Deepika, T. S. Johnson, G. K. Agrawal, and R. Rakwal. 2018. Proteomic studies on lactic acid bacteria: A review. Biochem. Biophys. Rep. 14:140-148.

Wang, F., J. Liu, L. Zhou, G. Pan, Z. Li, S. H. Zaidi, and F. Cheng. 2016a. Senescence-specific change in ROS scavenging enzyme activities and regulation of various SOD isozymes to ROS levels in psf mutant rice leaves. Plant Physiol. Biochem. 109:248-261.

Wang, Y., M. Chen, Y. Zhang, T. Huo, Y. Fang, X. Jiao, M. Yuan, and H. Jiang. 2016b. Effects of realgar on GSH synthesis in the mouse hippocampus: Involvement of system XAG(-), system XC(), MRP-1 and Nrf2. Toxicol. Appl. Pharmacol. 308:91-101.

Warner, H. R. 1994. Superoxide dismutase, aging, and degenerative disease. Free Radic. Biol. Med. 17:249-258.

Wei, Y., X. Q. Zeng, D. D. Pan, J. X. Cao, and H. S. Li. 2018. Identification of dominant lactic acid bacteria isolated from different fermented milk in Xinjiang of China. Appl. Sci. (Basel) 8:363.

Wells, S. M., and A. Holian. 2007. Asymmetric dimethylarginine induces oxidative and nitrosative stress in murine lung epithelial cells. Am. J. Respir. Cell Mol. Biol. 36:520-528.

Xing, Z., J. Lu, Z. Liu, S. Li, G. Wang, and X. Wang. 2016. Occurrence of perfluorooctanoic acid and perfluorooctane sulfonate in milk and yogurt and their risk assessment. Int. J. Environ. Res. Public Health 13:1037.

Yang, J., W. L. Zhang, J. J. Zou, M. Hu, X. L. Yuan, and Y. G. Liu 2015. Screening, identification and microflora analysis of Lactic acid bacteria from Xinjiang traditional yogurts. Sci. Technol. Food Ind. $36: 324-327$.

Zhang, J., X. Zhou, B. Chen, X. Long, J. Mu, Y. Pan, J. L. Song, X. Zhao, and Z. Yang. 2018. Preventive effect of Lactobacillus plantarum CQPC10 on activated carbon induced constipation in Institute of Cancer Research (ICR) mice. Appl. Sci. (Basel) 8:1498.

Zhao, C. F., X. Q. Zeng, D. D. Pan, and H. S. Li. 2012. The development of yogurt with cholesterol-lowering effects. J. Chin. Inst. Food Sci. Technol. 12:53-59.

Zhao, X., J. L. Song, R. Yi, G. Li, P. Sun, K. Y. Park, and H. Suo. 2018. Comparison of antioxidative effects of Insect tea and its raw tea (Kuding tea) polyphenols in Kunming mice. Molecules 23:204. 